\title{
Oxidation of Sulfur (IV) by Oxygen in Aqueous Solution: \\ Role of Some Metal Ions
}

\section{Claudia R. Martins, Clodovil A Cabral Neto, Janete J.F. Alves,} Jailson B. de Andrade*

\author{
Instituto de Química,UFBA, Campus de Ondina, 40.170.290 Salvador - Ba, Brazil
}

\begin{abstract}
No presente trabalho foi avaliado o papel de íons metálicos tais como: $\mathrm{Cr}$ (VI), $\mathrm{Cr}$ (III), Cd(II), $\mathrm{V}(\mathrm{V})$ e do íon cloreto, no processo de oxidação do S(IV) em solução aquosa. As concentrações dos íons metálicos, íon cloreto e do S(IV) foram escolhidas de modo a representarem as frações solúveis destes em aerossóis urbanos. Os estudos relativos ao processo de oxidação do S(IV) foram conduzidos em condições experimentais controladas tais como: $\left(\mathrm{pH}(2,1-4,5), \mathrm{T}\left(11,0-35,0{ }^{\circ} \mathrm{C}\right)\right.$, vazão de $\mathrm{O}_{2}$, concentração de reagentes, etc...). A constante cinética, $K$, determinada a $25,0{ }^{\circ} \mathrm{C}$ e na faixa de $\mathrm{pH}$ estudada (2,1-4,5), utilizando-se água pura, apresentou um valor médio de $8,0 \pm 0,5 \mathrm{x}$ $10^{-4} \mathrm{~s}^{-1}$, e este valor foi tomado como referência para reação de oxidação não catalisada. Os valores das constantes cinéticas determinadas, na presença de $\mathrm{Cr}(\mathrm{VI})$, revelaram que a reação de oxidação do S(IV) é bastante influenciada pela acidez do meio. Em pH 2,1 $\left(K=2,3 \times 10^{-2} \mathrm{mg}^{-1} \mathrm{~L} \mathrm{~s}^{-1}\right)$ a reação se processa com velocidade específica cinco vezes superior quando comparado a pH 2,6 $(K=4,3 \mathrm{x}$ $\left.10^{-3} \mathrm{mg}^{-1} \mathrm{~L} \mathrm{~s}^{-1}\right)$ e trinta vezes superior quando comparada a pH $3,4\left(K=8,0 \times 10^{-4} \mathrm{mg}^{-1} \mathrm{~L} \mathrm{~s}^{-1}\right)$. A seguinte expressão de velocidade foi obtida para o sistema envolvendo $\mathrm{Cr}(\mathrm{VI}) \mathrm{em} \mathrm{pH} \mathrm{2,6:-rS(IV)}=$ $K[\mathrm{Cr}(\mathrm{VI})]$ [S(IV)] e a energia de ativação encontrada foi: $\mathrm{E}_{\mathrm{a}}=70,3 \mathrm{~kJ} / \mathrm{mol}$. Não foi observado efeito catalítico para o íon metálico Cd(II) e para cloreto, porém efeitos catalíticos inibitórios foram observados para os íons $\mathrm{Cr}(\mathrm{III})$ e $\mathrm{V}(\mathrm{V})$.
\end{abstract}

Catalytic effect of metal ions: $\mathrm{Cr}(\mathrm{VI}), \mathrm{Cr}(\mathrm{III}), \mathrm{Cd}(\mathrm{II}), \mathrm{V}(\mathrm{V})$ and chloride anion, on the oxidation of $\mathrm{S}(\mathrm{IV})$ in aqueous solution, at concentrations of metal ions and S(IV) usually found in urban atmospheres, were studied under controlled experimental conditions ( $\mathrm{pH}(2.1$ - 4,5), $\mathrm{T}(25.0$ - 35.0 ${ }^{\circ} \mathrm{C}$ ), air flow rate, concentration of reactants, etc...). The kinetic constant determined at $25.0{ }^{\circ} \mathrm{C}$ and $\mathrm{pH}$ range (2.1 - 4.5), using ultra pure water was $8.0 \pm 0.5 \times 10^{-4} \mathrm{~s}^{-1}$. This value was considered as a reference for the oxidation reaction rate. The kinetic constants determined in the presence of $\mathrm{Cr}(\mathrm{VI})$ revealed that the oxidation reaction of $\mathrm{S}(\mathrm{IV})$ is quite influenced by the acidity. At $\mathrm{pH}=2.1(K=2.3$ $\left.\mathrm{x} 10^{-2} \mathrm{mg}^{-1} \mathrm{~L} \mathrm{~s}^{-1}\right)$ the reaction is carried out with a rate five times greater when compared to $\mathrm{pH}=$ $2.6\left(K=4.3 \times 10^{-3} \mathrm{mg}^{-1} \mathrm{~L} \mathrm{~s}^{-1}\right)$ and thirty times greater when compared to $\mathrm{pH}=3.4\left(K=8.0 \times 10^{-4}\right.$ $\left.\mathrm{mg}^{-1} \mathrm{~L} \mathrm{~s}^{-1}\right)$. The following rate expression was obtained at $\mathrm{pH}=2.6:-\mathrm{r}(\mathrm{S}(\mathrm{IV})=K[\mathrm{Cr}(\mathrm{VI})][\mathrm{S}(\mathrm{IV})]$ and the activation energy found was: $\mathrm{E}_{\mathrm{a}}=70.3 \mathrm{KJ} / \mathrm{mol}$. No catalytic effects were observed for $\mathrm{Cd}(\mathrm{II})$ or chloride ion, while inhibitory effects were observed for $\mathrm{Cr}(\mathrm{III})$ and $\mathrm{V}(\mathrm{V})$ ions.

Keywords: catalysis, aqueous $S(I V)$ oxidation, transition metals

\section{Introduction}

Typical urban atmosphere consists of a variety of anthropogenic air pollutants with particular regard to sulfur species in which dioxide is a major atmospheric pollutant ${ }^{1}$. The main sources of $\mathrm{SO}_{2(\mathrm{~g})}$ emissions are the burning of fossil fuels (e.g., power plants and mobile sources) and the smelting of ores rich in sulfur. In the atmosphere, $\mathrm{SO}_{2(\mathrm{~g})}$ can react with various oxidants (e.g., $\mathrm{O}_{2}, \mathrm{O}_{3}, \mathrm{H}_{2} \mathrm{O}_{2}$, NOx, $\mathrm{OH}$ radicals) to form sulfate aerosol, either as sulfuric acid droplets, or as neutralized particles such as ammonium sulfate, which play a special role in atmospheric processes like acid rain and visibility degradation ${ }^{1,2}$. There is evidence, however, that a significant portion of the airborne $\mathrm{S}$ species emitted to the environment may be particulate $\mathrm{SO}_{3}{ }^{2-2}$. This species has long residence times in the environment.

It is known that $\mathrm{SO}_{2(\mathrm{~g})}$, at the temperature of $400{ }^{\circ} \mathrm{C}$, reacts very slowly to produce $\mathrm{SO}_{3(\mathrm{~g})}$. In this way, the $\mathrm{SO}_{2(\mathrm{~g})}$ 
oxidation to sulfate aerosol, in the atmosphere, either homogeneously in the gas phase or heterogeneously in atmospheric microdroplets must be associated with other reaction processes such as photochemical oxidation or catalytic oxidation $^{2}$. These processes depend on a variety of factors such as intensity of incident solar radiation, relative humidity and, especially, the presence of transition metal ions which play a recognized role as catalysts ${ }^{3,4}$.

The oxidation of sulfur (IV) $\left(\mathrm{SO}_{2} . n \mathrm{H}_{2} \mathrm{O}, \mathrm{HSO}_{3}{ }^{-}, \mathrm{SO}_{3}{ }^{2-}\right)$ to sulfate, catalyzed by transition metal ions in aqueous microdroplets, has been acknowledged as a viable, nonphotolytic pathway, for the production of $\mathrm{H}_{2} \mathrm{SO}_{4}$ in fogs, clouds and humid atmospheres ${ }^{4}$. This has been studied systematically for more than one century, without a consense on the existence of a $\mathrm{pH}$ dependence, reaction rates and mechanisms, resulting in numerous and sometimes contradictory reports ${ }^{4}$. On the other hand, there is significant lack of information on either the behavior and the role of the transition metal on the catalyzed reactions, and much of the work was performed involving both S (IV) and transition metal ion concentrations several times greater than that found in typical urban atmosphere ${ }^{4,5}$.

It has been known that some transition-metal ions are able to catalyse or initiate the aqueous oxidation of sulfur (IV). The variation of catalytic abilities of the transition metal ions may be understood in terms of the accessibility of multiple oxidation states and the activation of metal ions in the high valence state. For a metal ion to be catalytically active, it must be able to ascend to a sufficiently high valence state to extract an electron from a S(IV) species, and thereby generate active intermediates which can propagate the reaction ${ }^{6}$. It seems to be generally accepted though that iron (II/III) and manganese (II/III) are the most efficient catalysts. An important aspect concerns the question of how the reduced metal ion species are reoxidized in order to complete the catalytic cycle. Some authors suggested that $\mathrm{Fe}$ (II) is oxidized back to Fe(III) by reaction with some of the radical species formed in the radical chain mechanism ${ }^{7}$.

The reports on oxidation of S(IV) catalyzed by transition metals are usually centered on metal ions such as: $\mathrm{Mn}(\mathrm{II}), \mathrm{Fe}(\mathrm{III})$ and $\mathrm{Cu}(\mathrm{II})^{5}$ in the presence of $\mathrm{O}_{2}$ saturated aqueous solution. In this work we investigated the role of $\mathrm{Cr}(\mathrm{VI}), \mathrm{Cr}(\mathrm{III}), \mathrm{Cd}(\mathrm{II}), \mathrm{V}(\mathrm{V})$ and $\mathrm{Cl}^{-}$ions on the oxidation of $\mathrm{S}(\mathrm{IV})$ by oxygen in the aqueous phase. The transition metal ion concentrations were chosen in order to represent their soluble fractions in urban aerosols ${ }^{8}$. The experiments were driven in the sense of determining the equations rates and their dependence on the $\mathrm{pH}$ and activation energy.

\section{Experimental}

\section{Materials}

All chemicals used in this study were of analytical reagent grade and all solutions were prepared using distilled water further purified in an E-pure system (Barnstead). Fresh solutions of $\mathrm{CrO}_{3}, \mathrm{CrCl}_{3}, \mathrm{CdCl}_{2}$., $\mathrm{NH}_{4} \mathrm{VO}_{3}$ and $\mathrm{NaCl}$ were used.

The calibration curves for $\mathrm{S}(\mathrm{VI})$ and $\mathrm{S}(\mathrm{IV})$ ) were made using stock solutions of $\mathrm{K}_{2} \mathrm{SO}_{4}\left(1 \mathrm{mg} \mathrm{mL}^{-1}\right)$ and $\mathrm{Na}_{2} \mathrm{~S}_{2} \mathrm{O}_{5}$ (1.2 $\mathrm{mg} \mathrm{mL}^{-1}$ in formaldehyde $10^{-2} \mathrm{~mol} \mathrm{~L}^{-1}$ ) in acetate buffer $\left(2 \mathrm{mmol} \mathrm{L}^{-1}\right)$. For the kinetic studies a fresh solution of $\mathrm{Na}_{2} \mathrm{~S}_{2} \mathrm{O}_{5},\left(1.2 \mathrm{mg} \mathrm{mL}^{-1}\right.$ without formaldehyde) was used. To adjust the $\mathrm{pH}$, solutions of $\mathrm{NaOH}\left(0.1 \mathrm{~mol} \mathrm{~L}^{-1}\right)$ and $\mathrm{HNO}_{3}(0.1 \mathrm{~mol} \mathrm{~L}-1)$ were used.

\section{Apparatus}

A Digimed Model DMPH-2 pH meter and an Analyzer 2 A13/AM microglass electrode were used for $\mathrm{pH}$ determinations. The measurements were performed at $25{ }^{\circ} \mathrm{C}$ and $35^{\circ} \mathrm{C}$. The clean air (as source of $\mathrm{O}_{2}$ ) was generated by a Zero Air Supplier (Thermo Environmental, Model 111).

The concentrations of S(IV) and S(VI) were determined using an ion chromatograph (IC) Dionex (Model 4000 i) equipped with a Rheodyne injector with a $20 \mu \mathrm{L}$ sample loop and a conductivity detector at $10 \mu \mathrm{S}$. The analytical column used was a Dionex AS9-SC followed by a fibrous micromembrane supressor Dionex AMMS-1. A $1.8 \mathrm{mmol}$ $\mathrm{L}^{-1} \mathrm{NaHCO}_{3}+1.7 \mathrm{mmol} \mathrm{L} \mathrm{Na}_{2} \mathrm{CO}_{3}$ eluent was used at a flow rate of $1.5 \mathrm{~mL} \mathrm{~min}^{-1}$. Different concentrations of $\mathrm{S}$ (IV) and $\mathrm{S}(\mathrm{VI})$ solutions, in the range of $1.0 \mathrm{mg} \mathrm{L}^{-1}$ to $5.0 \mathrm{mg}$ $\mathrm{L}^{-1}$, were injected in the ion chromatographic system, and the peak heights obtained were plotted against concentration. The IC determination was completed in about 7 min (Fig. 1) and no interferences were observed in both S(IV) and $\mathrm{S}(\mathrm{VI})$ retention times.

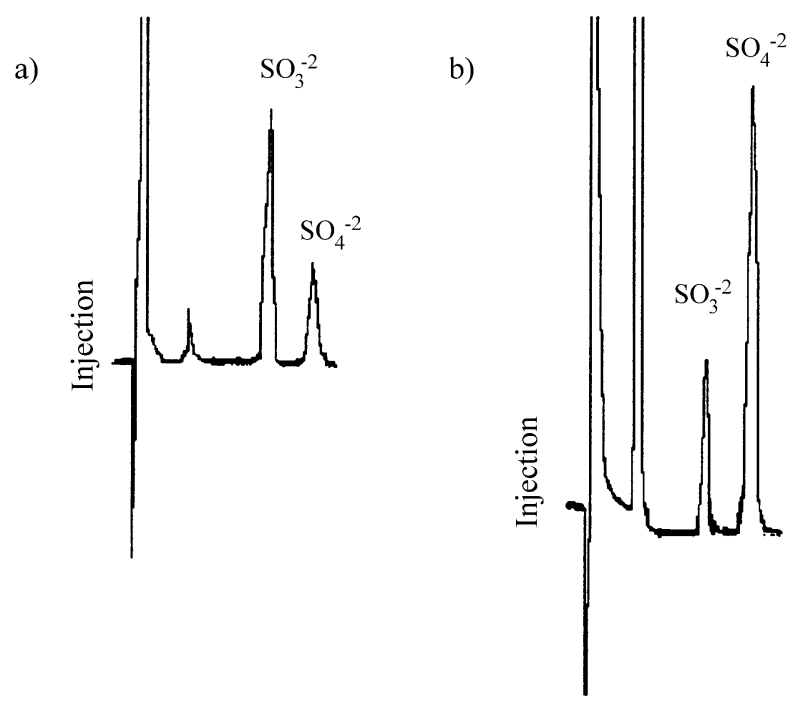

Figure 1. Typical chromatograms obtained for S(IV) and S(VI) standards (a); sample (b). Retention time is 4,90 min for S(IV) and 6,45 min for $\mathrm{S}(\mathrm{VI})$. 


\section{Procedure}

The kinetic studies were conducted in a laboratory reactor, which consists of a $500 \mathrm{~mL}$ round-bottom with three-neck (24/40 joints) thermostatized by means of a water bath (Fig. 2). The three inlets of the reaction flask were used: (2) rushton type turbine impeller; (3) introduction of reagents and (4) introduction of gas. Aliquots in the range of 1 to $3 \mathrm{~mL}$ of metal ion solution were introduced into the reactor and the $\mathrm{pH}$ was immediately adjusted by addition of variable amounts of $\mathrm{NaOH}$ or $\mathrm{HNO}_{3} 0.1 \mathrm{~mol} \mathrm{~L}^{-1}$ solutions. Then, $1.0 \mathrm{~mL}$ of fresh aqueous $\mathrm{S}(\mathrm{IV})$ solution $\left(1.2 \mathrm{mg} \mathrm{mL}^{-1}\right)$ was injected into the reactor at time $(\mathrm{t}=0)$. The total volume of reaction solution was adjusted to 150 $\mathrm{mL}$ and the initial concentration of S(IV) was set at 8.0 $\mathrm{mg} . \mathrm{L}^{-1}$. Then, the air was continuously bubbled through the aqueous solution at a flow rate of $1.0 \mathrm{~L} \mathrm{~min}^{-1}$. A mass flow meter was used to control the flow rate. Both gas and liquid phases were well mixed in the reactor.

Aliquots of $1 \mathrm{~mL}$ were taken after certain time intervals, and $1 \mathrm{~mL}$ of formaldehyde solution $\left(10^{-2} \mathrm{~mol} \mathrm{~L}^{-1}\right)$ was added immediately in order to quench S(IV) oxidation ${ }^{9,10}$. In this way, the oxidation reaction was stopped by the formation of hydroxymethanesulphonate according to the following reaction (Eq. 1):

$$
\mathrm{SO}_{3}{ }^{2-}+\mathrm{HCHO} \rightarrow{ }^{-} \mathrm{O}_{3} \mathrm{SHCHO}^{-}
$$

Once a stabilized solution was injected into the ion chromatography system, the signals of sulfate and sulfite (decomposition product of hydroxymethanesulphonate in mobile phase, basic media) were measured, and the concentrations of S(IV) and S(VI) were determined using the corresponding calibration curves. For comparative studies the oxidation reaction of S(IV) was followed under differ-

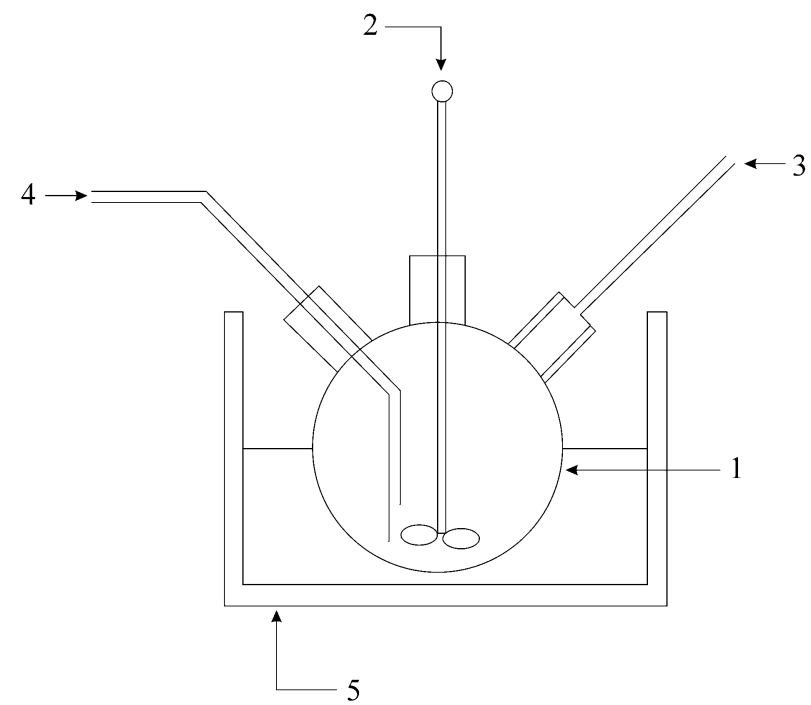

Figure 2. Apparatus for kinetics studies: (1) reactor vessel; (2) rushion type turbine; (3) introduction of reagents; (4) introduction of gas, and (5) water bath. ent circumstances, which consisted of passing clean air flow through the S(IV) solution, in the absence of transition metal ion or chloride ion. Figure 3 represents the oxidation by $\mathrm{O}_{2}$ in the absence of transition metal (Fig. 3a) and in the presence of $\mathrm{Cr}(\mathrm{IV})\left(1 \mathrm{mg} \mathrm{L}^{-1}\right.$, Fig. 3b). The difference in the half-life time, in the two systems, is approximately 26.

\section{Results and Discussion}

The oxygen used in this study was that of ambient air. Its solubility in pure water can be described by Henry's law (Eq. 2):

$$
c=\mathrm{H} p_{g}=\mathrm{H} y_{g} p
$$

where: $c=$ concentration of a gas in solution $\left(\mathrm{mol} \mathrm{L}^{-1} \mathrm{~atm}^{-1}\right)$, $p_{g}=$ partial pressure of a gas (atm), $p=$ total gas pressure above the solution in equilibrium (atm), $\mathrm{H}=$ Henry's constant ( $\left.\mathrm{mol} \mathrm{L}^{-1} \mathrm{~atm}^{-1}\right), Y_{g}=$ mole fraction.

If other substances are dissolved in the solution (e.g. $\mathrm{Na}_{2} \mathrm{SO}_{3}, \mathrm{Na}_{2} \mathrm{SO}_{4}, \mathrm{NaCl}$ ) the solubility of the oxygen decreases due to salting-out effect, and may not follow Henry's law ${ }^{4}$. The oxygen solubility in pure water, at 25.0 ${ }^{\circ} \mathrm{C}$, reported in the literature, is $1.27 \mathrm{mmol} \mathrm{L}^{-111,12}$ and this value did not show significant changes in the presence of $\mathrm{Na}_{2} \mathrm{SO}_{3} 50 \mathrm{mmol} \mathrm{L}^{-1}\left(1.25 \mathrm{mmol} \mathrm{L}^{-1}\right)^{13}$, which is compatible with the present study $\left(\mathrm{Na}_{2} \mathrm{SO}_{3} 0.25 \mathrm{mmol} \mathrm{L}{ }^{-1}\right)$.

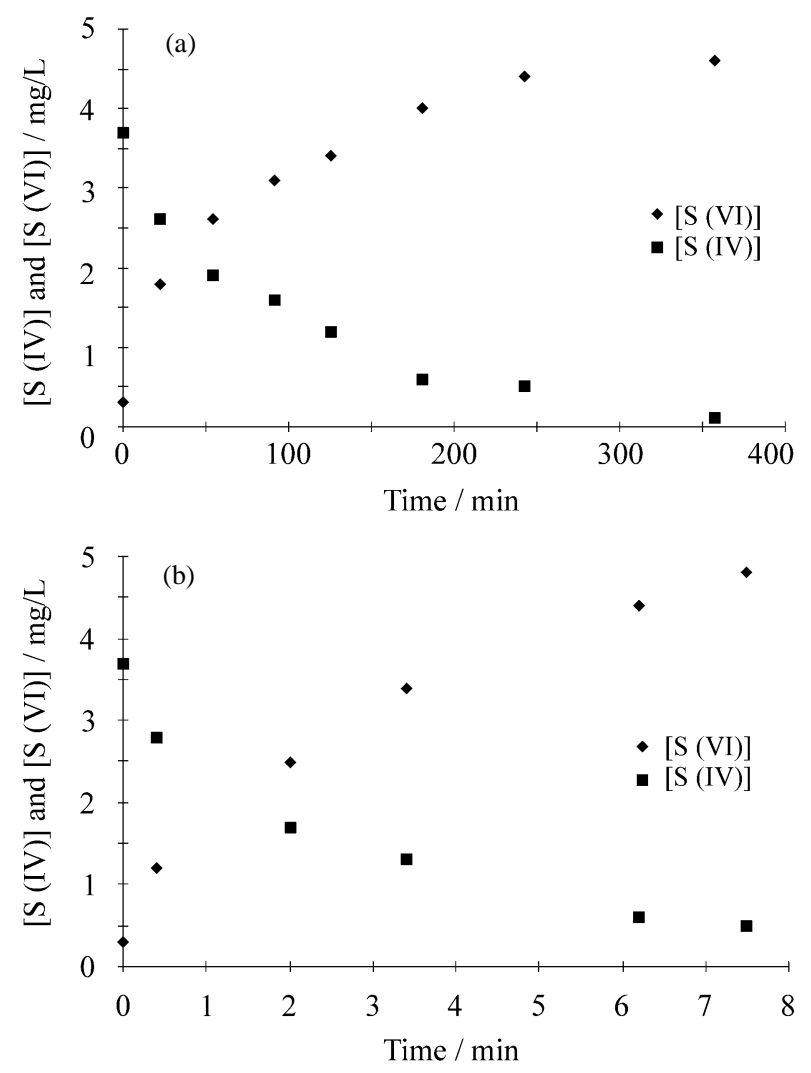

Figure 3. Oxidation of $\mathrm{S}(\mathrm{IV})_{(\mathrm{aq})}$ to $\mathrm{S}(\mathrm{VI})_{(\mathrm{aq})}$ by $\mathrm{O}_{2}$ at $\mathrm{pH} 2,1$; a) in purified water; b) in the presence of $\mathrm{Cr}(\mathrm{VI})(1 \mathrm{mg} / \mathrm{L})$. 
The rate constants for non catalyzed oxidation reactions of S(IV) were determined by passing clean air flow through the S(IV) solution, in the absence of transition metal ion or chloride ion. Special attention must be paid to the purity of the water, because traces of transition metal, which remain in the water as a result of deficiencies in the purification process, can enhance the rate constant. For example, differences in rate constant values (determined at $25.0^{\circ} \mathrm{C}$ and $\mathrm{pH}$ 8.2-8.9), seven times slower, were observed for the non catalyzed reaction when using Milli R/Q water $\left(1.3 \times 10^{-5}\right.$ $\left.\mathrm{s}^{-1}\right)$ instead of deionized water $\left(9.5 \times 10^{-5} \mathrm{~s}^{-1}\right)^{14}$. In this study, the determined value $\left(25^{\circ} \mathrm{C}\right.$ and $\mathrm{pH}$ range $\left.2.1-4.5\right)$ was $8.0 \pm 0.5 \times 10^{-4} \mathrm{~s}^{-1}$. This value was used throughout this study as a non catalyzed constant for the oxidation reaction rate.

\section{Chromium (VI)}

The two oxidation states of chromium commonly found in the environment are trivalent chromium, the predominant species in the atmospheric aqueous phase, and hexavalent chromium, a powerful oxidizing agent, for which the rate reaction with $\mathrm{S}(\mathrm{IV})$ decreases with decreasing acidi$\mathrm{ty}^{15}$. In this way, the reaction rate for catalyzed aqueous $\mathrm{S}(\mathrm{IV})\left(8.0 \mathrm{mg} \mathrm{L}^{-1}\right)$ oxidation was studied in the presence of $\mathrm{Cr}(\mathrm{VI})$ at three different concentrations $(0.2,0.5$ and $1.0 \mathrm{mg}$ $\left.\mathrm{L}^{-1}\right)$, at a $\mathrm{pH}$ range of $2.0-4.5$ and temperatures of 11.0, 25.0 and $35.0^{\circ} \mathrm{C}$. In all experiments the $\mathrm{Cr}(\mathrm{VI})$ concentration was, at least eight times lower than the S(IV) concentration. At the end of the experiments, at least, $80 \%$ of the initial $\mathrm{Cr}(\mathrm{VI})$ concentration remains in the same oxidation state.

Figure 3 represents the $\mathrm{S}(\mathrm{IV})$ oxidation by $\mathrm{O}_{2}$ in absence of transition metal (Fig. 3a) and in the presence of $\mathrm{Cr}(\mathrm{IV}$ ) (1 $\mathrm{mg} \mathrm{L}^{-1}$, Fig. 3b). The difference in the half-life time, in the two systems, is approximately 26 times.

The reaction order ${ }^{16}$ was obtained graphically by plotting $-\ln [\mathrm{S}(\mathrm{IV}) /[\mathrm{S}(\mathrm{IV}) \mathrm{o}]$ versus the reaction time. The plots indicate the first-order dependence in relation to $\mathrm{S}(\mathrm{IV})$ concentration, Fig. 4. From the slopes, the apparent constants ( $\mathrm{k}^{\prime}$ ) were determined. It was observed that $\mathrm{k}^{\prime}$ is proportional to the $\mathrm{Cr}(\mathrm{VI})$ concentrations, Fig. 5. Thus, this kinetic behavior indicates also that the S(IV) oxidation in the presence of $\mathrm{Cr}(\mathrm{VI})$ is of first-order in relation to $\mathrm{Cr}(\mathrm{VI})$ concentration. According to experimental data, the following rate Eq. (3) can be written:

$$
-\mathrm{r}_{\mathrm{S}(\mathrm{IV})}=+\mathrm{r}_{\mathrm{S}(\mathrm{VI})}=K[\mathrm{~S}(\mathrm{IV})][\mathrm{Cr}(\mathrm{VI})]
$$

Table 1 summarizes the S(IV) oxidation rates as function of $\mathrm{Cr}(\mathrm{VI})$ concentration, temperature and $\mathrm{pH}$ dependence. The rate constants $(K)$ determined at $\mathrm{pH} 2.6$ and temperature of $11.0,25.0$ and $35.0^{\circ} \mathrm{C}$ were $1.2 \times 10^{-3} \mathrm{mg}^{-1}$ $\mathrm{L} \mathrm{s}^{-1}, 4.3 \times 10^{-3} \mathrm{mg}^{-1} \mathrm{~L} \mathrm{~s}^{-1}$ and $1.1 \times 10^{-2} \mathrm{mg}^{-1} \mathrm{~L} \mathrm{~s}^{-1}$ respectively. Similar behavior was observed for $\mathrm{S}(\mathrm{IV})$ oxi- dation rate when $\mathrm{Mn}(\mathrm{II})$ was employed ${ }^{5}$. The S(IV) oxidation rate in $\mathrm{O}_{2}$ saturated aqueous solution catalyzed by

Table 1. S(IV) oxidation rates as function of $\mathrm{Cr}(\mathrm{VI})$ concentration, temperature and $\mathrm{pH}$.

\begin{tabular}{lcccc}
\hline $\begin{array}{l}{[\mathrm{Cr}(\mathrm{VI})]} \\
\left(\mathrm{mg} \mathrm{L}^{-1}\right)\end{array}$ & $\mathrm{pH}$ & $\begin{array}{c}\text { Temp. } \\
\left({ }^{\circ} \mathrm{C}\right)\end{array}$ & $\begin{array}{c}\mathrm{k}_{\mathrm{a}} \\
\left(\mathrm{s}^{-1}\right)\end{array}$ & $\begin{array}{c}K \\
\left(\mathrm{mg}^{-1} \mathrm{~L}^{-1} \mathrm{~s}^{-1}\right)\end{array}$ \\
\hline 0.25 & 2.6 & 11.0 & $3.0 \times 10^{-4}$ & \\
0.40 & 2.6 & 11.0 & $5.0 \times 10^{-4}$ & $1.2 \times 10^{-3}$ \\
0.60 & 2.6 & 11.0 & $7.0 \times 10^{-4}$ & \\
1.00 & 3.4 & 25.0 & $8.0 \times 10^{-4}$ & \\
1.00 & 4.5 & 25.0 & $9.0 \times 10^{-4}$ & \\
1.00 & 2.1 & 25.0 & $2.4 \times 10^{-2}$ & \\
0.50 & 2.1 & 25.0 & $1.0 \times 10^{-2}$ & $2.3 \times 10^{-2}$ \\
0.20 & 2.1 & 25.0 & $5.2 \times 10^{-3}$ & \\
1.00 & 2.6 & 25.0 & $4.4 \times 10^{-3}$ & \\
0.50 & 2.6 & 25.0 & $2.2 \times 10^{-3}$ & $4.3 \times 10^{-3}$ \\
0.20 & 2.6 & 25.0 & $5.0 \times 10^{-3}$ & \\
1.00 & 2.6 & 35.0 & $1.2 \times 10^{-2}$ & \\
0.50 & 2.6 & 35.0 & $6.3 \times 10^{-3}$ & $1.1 \times 10^{-2}$ \\
0.20 & 2.6 & 35.0 & $1.4 \times 10^{-3}$ & \\
& & & & \\
\hline
\end{tabular}

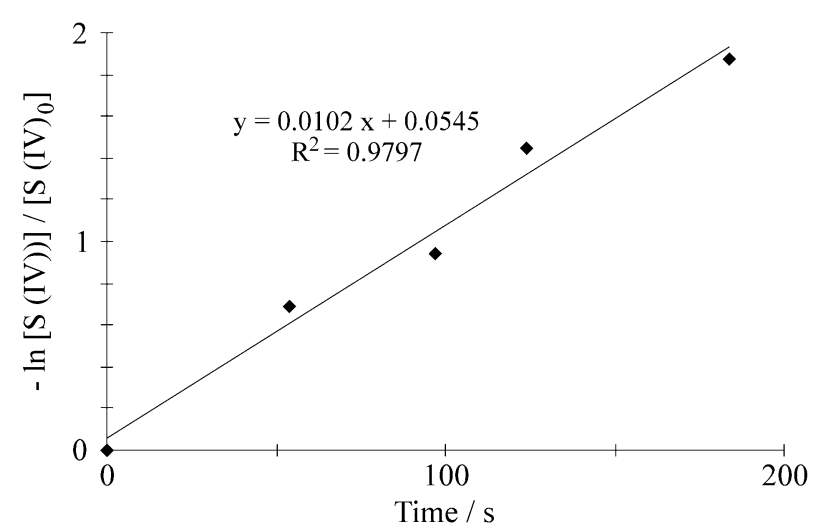

Figure 4. Time dependence of $\left\{-\ln [\mathrm{S}(\mathrm{IV})] /\left[\mathrm{S}(\mathrm{IV})_{\mathrm{o}}\right]\right\}$ for $\mathrm{S}(\mathrm{IV})$ oxidation in the presence of $[\mathrm{Cr}(\mathrm{VI})]=0,5 \mathrm{mg} / \mathrm{L}, \mathrm{T}=25^{\circ} \mathrm{C}, \mathrm{pH}=2,1$.

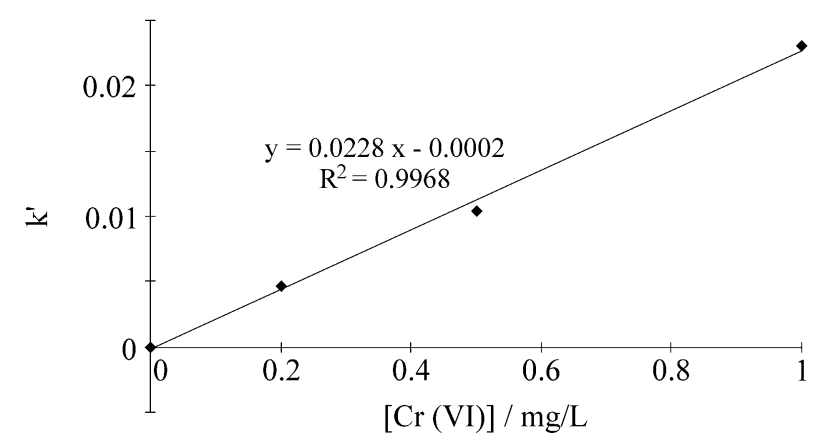

Figure 5. The dependence of $\mathrm{k}^{\prime}$ upon $\mathrm{Cr}(\mathrm{VI})$ concentrations, $\mathrm{T}=25^{\circ} \mathrm{C}$, $\mathrm{pH}=2,1$. 
$\mathrm{Cr}(\mathrm{VI})$ is also influenced by acidic media. At pH 2.1 and temperature of $25^{\circ} \mathrm{C}$, the $\mathrm{S}(\mathrm{IV})$ oxidation rate is increased by a factor of 5 and 30 when compared to that measured at $\mathrm{pH} 2.6$ and 3.4, respectively. It is known that the oxygen solubility decreases with decreasing $\mathrm{pH}^{4}$ and that there is an equilibrium between $\mathrm{HCrO}_{4}^{-}$and $\mathrm{Cr}_{2} \mathrm{O}_{7}{ }^{2-}$ ions in aqueous solution containing $\mathrm{Cr}(\mathrm{VI})$ at $\mathrm{pH}$ range 2 to $6^{17}$. Probably, this observed reaction rate difference can be due to the presence of different chromium species, depending upon the $\mathrm{pH}$. On the other hand, the S(IV) oxidation rate at $\mathrm{pH} 3.4$, or higher, is the same as measured in the absence of $\mathrm{Cr}(\mathrm{VI})\left(K=8.0 \times 10^{-4} \mathrm{~s}^{-1}\right)$. Thus, under these conditions, no catalytic effect was observed.

The activation energy was determined graphically by plotting $-\ln K$ vs. 1/T (Fig. 6), at pH 2.6 and temperatures of 11.0, 25.0 and $35.0^{\circ} \mathrm{C}$.respectvely. It was found to be $70.3 \mathrm{~kJ} \mathrm{~mol}^{-1}$. This value is comparable to that previously determined by Ibusuki and Barnes ${ }^{18}$ in the presence of $\mathrm{Mn}(\mathrm{II}): \mathrm{E}_{\mathrm{a}}=74.3 \mathrm{~kJ} \mathrm{~mol}^{-1}$ or that determined by Grgic et $a l .{ }^{5}$ in the presence of $\mathrm{Mn}(\mathrm{II}), \mathrm{Fe}(\mathrm{III})$ and $\mathrm{Cu}(\mathrm{II}): \mathrm{E}_{\mathrm{ac}}=63.3$ $\mathrm{kJ} \mathrm{mol}^{-1} ; \mathrm{E}_{\mathrm{a}}=104 \mathrm{~kJ} \mathrm{~mol}^{-1} ; \mathrm{E}_{\mathrm{a}}=116 \mathrm{~kJ} \mathrm{~mol}^{-1}$, respectively. In the more acidic water shells of aerosols or acidic fog and cloud droplets, chromium (VI) - initiated oxidation of sulfur (IV) might be of some importance for the acidification.

\section{Chromium (III)}

The influence of $\mathrm{Cr}$ (III) $\left(1,0 \mathrm{mg} \mathrm{L}^{-1}\right)$ on the oxidation of $\mathrm{S}(\mathrm{IV})$ in $\mathrm{O}_{2}$ - aqueous solution was studied at $\mathrm{pH} 3$ and 5.2 and temperature of $25^{\circ} \mathrm{C}$. Under these conditions, inhibitory effect of $\mathrm{Cr}$ (III) was observed. Even after six hours the sulfite and sulfate peaks remain constant, and no oxidation reaction could be observed. It is in agreement with the Brandt and Elding ${ }^{19}$ observations after mixing $\mathrm{Cr}(\mathrm{III})$ with tenfold excess of $\mathrm{S}$ (IV) at $\mathrm{pH} 3$. A chromium (III)-sulfite complex was formed rapidly. Indeed, $\mathrm{Cr}$ (III) only plays a role in the uptake process and that is why it is not catalytically active ${ }^{17}$.

\section{Cadmium (II)}

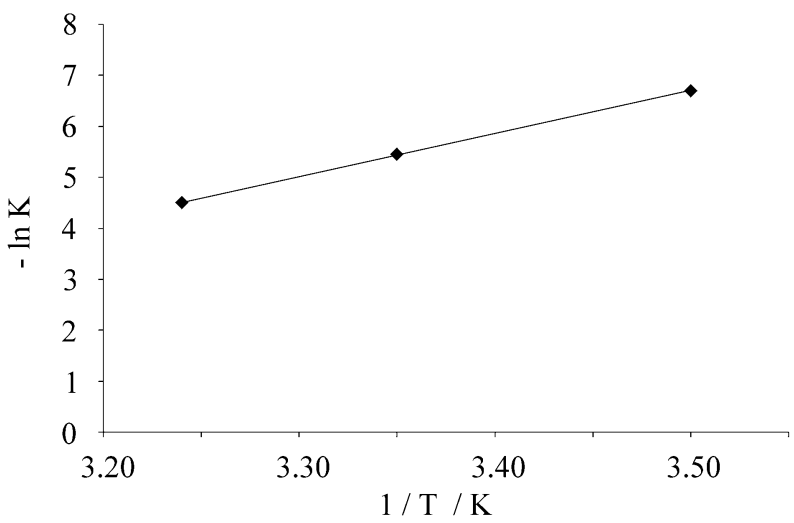

Figure 6. Temperature dependence of the first order rate constant $K$ in $\mathrm{Cr}(\mathrm{VI})$ catalyzed $\mathrm{S}(\mathrm{IV})$ oxidation in aqueous solution ( $\mathrm{pH} 2,6)$.
The influence of $\mathrm{Cd}(\mathrm{II})$ on the oxidation of $\mathrm{S}(\mathrm{IV})$ in aqueous phase was studied at $\mathrm{pH} 3.0$ and 5.2 and temperature of $25{ }^{\circ} \mathrm{C}$. The $\mathrm{Cd}(\mathrm{II})$ concentrations were 0.2 and 4.4 $\mathrm{mg} \mathrm{L}^{-1}$. Independently of the $\mathrm{pH}$ and $\mathrm{Cd}(\mathrm{II})$ concentration employed, the rate constant was the same as observed in the absence of $\mathrm{Cd}(\mathrm{II})$. Thus, no catalytic effect of $\mathrm{Cd}(\mathrm{II})$ was observed.

\section{$\operatorname{Vanadium}(V)$}

The influence of $\mathrm{V}(\mathrm{V})\left(1,0 \mathrm{mg} \mathrm{L}^{-1}\right)$ on the oxidation of $\mathrm{S}(\mathrm{IV})$ in aqueous phase at $\mathrm{pH} 3.0$ and 5.2 and temperature of $25^{\circ} \mathrm{C}$ was studied. Under these conditions, an inhibitory effect of V (V) was observed. Even after six hours the sulfite and sulfate peaks remain constant, and no oxidation reaction could be observed. Very little is known about the role of $\mathrm{V}(\mathrm{V})$ in atmospheric redox processes ${ }^{17}$. At $\mathrm{pH}<3.0$, $\mathrm{VO}_{2}{ }^{+}$is the dominant $\mathrm{V}(\mathrm{V})$ species, and it reacts very slowly with $\mathrm{HSO}_{3}{ }^{-}$. In slightly acidic solutions $(4.0<\mathrm{pH}<6.0)$ the formation of polyoxovanadates occurs and their influence on the S(IV) oxidation is unknown.

\section{Chloride}

Clarke and Rodojevic ${ }^{14}$ discovered significant anion catalysis by $\mathrm{Cl}^{-}$(concentrations higher than $35 \mathrm{mg} \mathrm{L}^{-1}$ ), on $\mathrm{S}(\mathrm{IV})\left(3.2 \mathrm{mg} \mathrm{L}^{-1}-0.32 \mathrm{mg} \mathrm{L}^{-1}\right)$ oxidation. On the other hand, Grgic et al. ${ }^{5}$ did several experiments using metal chlorides, in the which the $\mathrm{Cl}^{-}$concentrations were lower than $0.35 \mathrm{mg} \mathrm{L}^{-1}$. In this case the chloride catalytic effect was negligible. In the present study, the following conditions were used: chloride concentrations $10 \mathrm{mg} \mathrm{L}^{-1}$ and 40 $\mathrm{mg} \mathrm{L}^{-1}$; $\mathrm{pH} 3.0$ and 5.2; temperature of $25{ }^{\circ} \mathrm{C}$; and $\mathrm{S}(\mathrm{IV})$ concentration $8.0 \mathrm{mg} \mathrm{L}^{-1}$. Under these conditions no catalytic effect was observed.

\section{Conclusions}

The present study shows the first-order dependence of aqueous phase $S(I V)$ catalytic oxidation on both $S(I V)$ and $\mathrm{Cr}(\mathrm{VI})$ concentration over the $\mathrm{pH}$ range of 2.1 to 2.6. No catalytic effects were observed for $\mathrm{Cd}(\mathrm{II})$ or chloride ions, and inhibitory effects were observed for $\mathrm{Cr}(\mathrm{III})$ and $\mathrm{V}(\mathrm{V})$ ions. Only in very acidic droplets, direct redox between chromium (VI) and sulfite might be of some importance.

The rate expression, rate constant, activation energy and $\mathrm{pH}$ dependence determined would be useful for evaluation of metal catalytic oxidation of S(IV) in aquatic systems, wetted atmospheric aerosols or water droplets. Other studies on this system are in progress at this Laboratory and will be reported later.

\section{Acknowledgments}

The authors are indebted to CNPq, CAPES and FINEP for financial support, and to Prof. Dr. Pedro Afonso de Paula Pereira Pereira and Prof. Dr. José Oscar Nogueira Reis for helpful discussions. 


\section{References}

1. Eatough, D.J.; Caka, F.M.; Farber, R.J. Israel J. Chem. $1994,301$.

2. Cox, X.B.; Linton, R.W.; Miguel, A.M.; de Andrade, J.B. Atmos. Environ. 1986, 20, 1139.

3. Calvert, J.G., Acid Precipitation Series; Teasley, J.I., Series Ed.; Butterworth Publishers: Boston; v. 3,1984.

4. Brandt, C.;van Eldik, R. Chem. Rev. 1995, 95, 119.

5. Grgic, I.; Hudnik,V.; Bizjak, M.; Levec, J. Atmos. Environ. 1991, 25A, 1591.

6. Huss, A.; Lim, K.P.Jr; Eckert.; C.A. J.Phys.Chem. 1982, 86, 4224.

7. Brandt, C.; Fábian, I.; van Eldik, R. Inorg. Chem. 1994, 33, 687.

8. de Andrade, J.B.; Macedo, M.A.; Korn, M.; Oliveira, A.E.; Gennari, R.F. Toxicol. Environ .Chem. 1996, 54, 23.

9. de Andrade, J.B.; Tanner, R.L. Atmos. Environ. 1992, 26, 1992.

10.
Oliveira, A.O ; de Andrade, J.B. Química Nova 1994, 17, 13.

11. Messer Griesheim GmbH, Gase Handbuch, 3rd Ed.; Messer Griesheim GmbH: Dusseldorf, Germany, 1986.

12. IUPAC Solubility Data Series; Battino, R., Pergamon Press: Oxford; v. 7, 1981.

13. Gestrich, W.; Pontow, B. Chem. Ing. Tech. 1977, 49, 564.

14. Clarke, A.G.; Radojevic, M. Atmos. Environ. 1983, 17, 617.

15. Seigneur, Ch.; Constantinou, E. Environ. Sci.Technol. 1995, 29, 222.

16. Levenspiel, O. Engenharia das Reações Químicas, Edgard Blucher, v. 1, São Paulo, p. 44, 1983.

17. Cotton, F.A., Wilkinson, G. Advanced Inorganic Chemistry: A Comprehensive Text John Willey Sons, 4th Ed., 1980, p. 733.

18. Ibusuki, T.; Barnes, H.M. Atmos. Environ. 1984, 18, 145.

19. Brandt C.; Elding L.I. Atmos. Environ. 1998, 32, 797. 